\title{
The Prenatal Development and Glucocorticoid Control of Brush-Border Hydrolases in the Pig Small Intestine
}

\author{
PER T. SANGILD, HANS SJÖSTRÖM, OVE NORÉN, ABIGAIL L. FOWDEN, AND \\ MARIAN SILVER \\ Department of Clinical Studies, Reproduction, Royal Veterinary and Agricultural University, Copenhagen, \\ Denmark [P.T.S.], Department of Medical Biochemistry and Genetics, Biochemistry Laboratory C, \\ University of Copenhagen, Panum Institute, Copenhagen, Denmark [H.S., O.N.], and Physiological \\ Laboratory, University of Cambridge, Cambridge, United Kingdom [A.L.F., M.S.]
} \begin{abstract}
ABS
The development of brush-border enzymes and the possible
regulatory role of cortisol were investigated in the small intestine of the fetal and neonatal pig. With the sows under pentobarbitone anesthesia, osmotic minipumps containing either saline or cortisol were inserted s.c. into 25 fetuses from 10 pregnant sows (82-96 d gestation). Six $d$ later, the infused fetuses were removed by cesarean section and samples of the proximal, middle, and distal intestine taken for analysis. Samples were also obtained from 48 piglets that did not undergo an operation (controls) and that were removed at intervals from $82 \mathrm{~d}$ gestation until term $(114 \pm 2 \mathrm{~d})$. In the proximal and middle intestine, the mean levels of lactase-phlorizin hydrolase (EC 3.2.1.23-62), maltaseglucoamylase (EC 3.2.1.20), aminopeptidase N (EC 3.4.11.2), and aminopeptidase A (EC 3.4.11.7) increased during the last
\end{abstract}

$10-15 \mathrm{~d}$ before term, correlated positively with $\log _{10}$ plasma cortisol values, and were higher in cortisol-infused than in saline-infused fetuses $(p<0.05)$. Activity of sucrase-isomaltase (EC 3.2.1.48-10) was low in fetal pigs, and this enzyme and dipeptidyl peptidase IV (EC 3.4.14.5) were not significantly affected by fetal age or exogenous cortisol. Maltase (EC 3.2.1.48-10 and EC 3.2.1.20) activity was significantly decreased in the middle and distal intestine of cortisol-infused fetuses. The results suggest that the prepartum rise in endogenous cortisol secretion stimulates the prenatal expression of certain brush-border enzymes in the pig small intestine at this critical time. However, the effects of cortisol on the developing intestine were highly idiosyncratic for particular enzymes and intestinal regions. (Pediatr Res 37: 207-212, 1995)
Brush-border enzymes in the small intestine are nutritionally important for the hydrolysis of carbohydrates and peptides into monosaccharides and small peptides or amino acids. Development of intestinal hydrolase activities in the fetus is therefore an essential maturational event that ensures that the gut can handle the oral uptake of nutrients after birth.

Although the developmental regulation of brush-border enzymes has been much investigated in rodents, little is known about these processes in species such as the pig, in which the rate of gut development resembles that in the human infant (1-3). In the suckling rat, exogenous administration of glucocorticoids stimulates development of the sucrase and maltase activity of sucrase-isomaltase (EC 3.2.1.48-10) at 2-4 wk of age when the plasma glucocorticoid level normally reaches a peak (4-8). Whether the hormones have a role in the postnatal

Received February 15, 1994; accepted August 17, 1994.

Correspondence: Per Sangild, Ph.D., Department of Clinical Studies, Reproduction, Royal Veterinary and Agricultural University, 13 Bülowsvej, DK-1870 Frederiksberg C, Denmark.

Supported by The Welicome Trust, NOVO Foundation, and the Danish Agricultural and Veterinary Research Council. decline of lactase activity is less clear, because both increases and decreases in lactase activity have been found in response to exogenous glucocorticoids $(6,9)$. In the pig, adrenocortical secretion reaches a peak at birth (10) and pharmacologic doses of glucocorticoids have little effect on disaccharidase activities in the suckling pig (11-14). Hence, it is possible that, in the pig, glucocorticoids have their primary regulatory role in the ontogeny of gut enzymes in the prenatal and immediate postnatal period.

In the present study, we tested the hypothesis that cortisol stimulates the ontogenetic development of brush-border disaccharidases and peptidases in the fetal pig. Two questions were asked: 1) Are the normal prenatal developmental profiles of plasma cortisol and enzyme activities consistent with a regulatory role of glucocorticoids? 2) Does exogenous glucocorticoid infusion into fetuses induce early development of enzyme activity?

\section{METHODS}

Animals. Sixteen pregnant Large White cross Welsh sows of known gestational age (term $114 \pm 2$ d) were used for the 
experiments. They were maintained on commercial sow feed (Sowcare Gold 16, BOCM Silcock, Cambridge, UK). Food but not water was withheld on the night before surgery. Infused fetuses $(n=25)$ were removed either at $88-90 \mathrm{~d}$ or $97-102 \mathrm{~d}$ gestation, whereas fetuses that did not undergo an operation (control fetuses) $(n=48)$ were removed at intervals throughout late gestation (82-109 d gestation) as shown in Table 1 . The control fetuses were obtained from the sows used for the infusion experiments $(n=10)$ as well as from other pregnant sows $(n=6)$. Nine newborn unsuckled pigs were obtained immediately after normal birth (114-115 d gestation) from six sows that did not undergo an operation.

Surgical procedures. Details of the surgical procedures for fetal and maternal intravascular catheterization and the insertion of 7-d osmotic minipumps (model 2001, Alzet, Palo Alto, $\mathrm{CA}$ ) into fetuses have been given previously $(15,16)$. Each pump had been filled before insertion with a $200-\mu \mathrm{L}$ sterile solution of either $0.9 \%$ saline or cortisol (E.F. Cortilan, Glaxo, Greenford, UK). The dose of cortisol was $10 \mathrm{mg}$ for fetuses at 82-84 d gestation and 20 or $40 \mathrm{mg}$ at 91-96 d gestation (Table 1) corresponding to dose rates of $3-6 \mathrm{mg} \mathrm{cortisol} \cdot \mathrm{kg}^{-1} \cdot \mathrm{d}^{-1}$ over the 6-d period. The aim was to increase plasma cortisol concentration by $20-30 \mathrm{ng} / \mathrm{mL}$, and the dose rates were based on results from a previous study (17). At 91-96 d gestation, 10 fetuses with minipumps also had carotid arterial catheters inserted (Table 1) to enable blood samples to be taken during the treatment period for measurement of blood gases and plasma cortisol. The remaining four fetuses with cortisolcontaining minipumps were not catheterized. After fetal surgery, the fetuses received $50 \mathrm{mg}$ of ampicillin (Penbitrin, Beecham Labs, Tadworth, UK) into the amniotic cavity. The sows were maintained on antibiotics for 3-4 d from the time of surgery $(20 \mathrm{~mL}$ of Depocillin intramuscularly; Mucofarm, Cambridge, UK).

Six d after insertion of the minipumps, infused and control fetuses were delivered by cesarean section under general anesthesia (40 mg of sodium pentobarbitone per $\mathrm{kg}$ ). All catheterized piglets were sampled through their catheter just before delivery; fetuses that did not undergo an operation or fetuses with minipumps but without catheters were sampled by direct puncture of the umbilical artery before removal. Of 27 fetuses implanted with minipumps, 25 were alive at the time of delivery. The normal newborn piglets (114-115 d gestation) were sampled from the cord within $10 \mathrm{~min}$ of delivery.
Blood and plasma analysis. Blood gases, $\mathrm{pH}, \mathrm{Hb}$ concentration, and oxygen saturation were measured (Acid Base Laboratory and Haemoxymeter, Radiometer, Copenhagen, Denmark) daily in the catheterized piglets and at delivery in all piglets. The values obtained were within the range reported previously for chronically catheterized fetuses (17). At delivery, arterial blood samples were placed in cooled EDTAcontaining tubes and centrifuged, and the plasma was stored at $-20^{\circ} \mathrm{C}$ until analysis. Plasma cortisol concentrations were measured using an RIA described and validated for fetal pig plasma (18).

Tissue collection and preparation. After delivery, the fetuses (anesthetized during surgery) and newborn pigs (anesthetized with halothane, 3-5\% in oxygen) were weighed, had their abdomen opened, and were killed by being bled from the heart. The adrenal glands were removed and their combined weight was determined. The intestine was dissected free of its mesentery, placed on ice, and divided into three parts of equal length. The middle $10 \mathrm{~cm}$ of each piece was cut open lengthwise, blotted dry on filter paper, and stored at $-80^{\circ} \mathrm{C}$ until enzyme analysis. The proximal segment (17\% down the intestine) was distal to the ligament of Treitz and can be defined as proximal jejunum. The distal segment (83\% down the intestine) represented the distal jejunum or proximal ileum in the pig.

The fetal pig intestine was fragile, especially for the earliest age groups, and whole tissue was used for analysis rather than mucosal scrapings. Frozen intestinal tissue was cut into fine pieces, extracted in $1 \%$ Triton $\mathrm{X}-100(6 \mathrm{~mL} / \mathrm{g}$ tissue), homogenized $\left(20000 \mathrm{rpm}, 2 \mathrm{~min}, 0^{\circ} \mathrm{C}\right.$; Ultra Turax, IKALabortechnik, Stauten, Germany), and centrifuged $(20000 \times$ $\left.g, 4^{\circ} \mathrm{C}, 60 \mathrm{~min}\right)$, and the supernatant was used for enzyme analysis. Before centrifugation, a $20-\mu \mathrm{L}$ aliquot was taken for measurement of protein (19). The nonionic detergent Triton $\mathrm{X}-100$ was used for extraction to solubilize the microvillus enzymes, which allowed the extracts to be used for gel electrophoresis, after measurements of enzyme activity (20).

Enzyme analyses. Disaccharidase activities were measured using disaccharide substrates $(28 \mathrm{mM})$ and sodium maleate, $\mathrm{pH}$ $6.0(50 \mathrm{mM})$, as buffer in the reaction mixture $\left(37^{\circ} \mathrm{C}, 30 \mathrm{~min}\right)$. The liberated glucose was determined spectrophotometrically at $492 \mathrm{nM}$ (EAR 400 AT, SLT Lab Instruments, Grödig, Austria) using a glucose-oxidase kit (510-A, Sigma Chemical Co., St. Louis, MO). One activity unit (U) was equal to $1 \mu \mathrm{mol}$

Table 1. Experimental protocol

\begin{tabular}{|c|c|c|c|c|c|}
\hline $\begin{array}{c}\text { Fetal age }(\mathrm{d}) \\
\text { at surgery }\end{array}$ & No. of sows & No. of fetuses & $\begin{array}{l}\text { Surgical } \\
\text { procedure }\end{array}$ & Treatment $(6 \mathrm{~d})$ & $\begin{array}{c}\text { Fetal age (d) } \\
\text { at autopsy }\end{array}$ \\
\hline No surgery & 6 & 5 & & & $82-84$ \\
\hline No surgery & 6 & 8 & & & $88-90$ \\
\hline $82-84$ & 5 & 5 & MP & Saline & $88-90$ \\
\hline $82-84$ & 6 & 6 & MP & Cortisol (10 mg) & $88-90$ \\
\hline $91-96$ & 4 & 4 & Cath + MP & Saline & $97-102$ \\
\hline $91-96$ & 4 & 6 & Cath + MP & Cortisol (20-40 mg) & $97-102$ \\
\hline $91-96$ & 4 & 4 & MP & Cortisol $(20-40 \mathrm{mg})$ & $97-102$ \\
\hline No surgery & 8 & 10 & & & $97-102$ \\
\hline No surgery & 6 & 16 & & & $106-109$ \\
\hline No surgery & 6 & 9 & & & $114-115$ \\
\hline
\end{tabular}

MP, minipump (200- $\mu \mathrm{L}$ capacity); Cath, fetal carotid artery catheter. 
Table 2. Mean values \pm SEM for body weight, relative adrenal gland weight (combined weight per kg body weight), and intestinal protein in fetal pigs (untreated, saline infused, and cortisol infused) and newborn pigs (114-115 d gestation) at delivery

\begin{tabular}{|c|c|c|c|c|c|c|c|}
\hline \multirow{2}{*}{$\begin{array}{l}\text { Fetal age at } \\
\text { delivery (d) }\end{array}$} & \multirow[b]{2}{*}{ Treatment } & \multirow[b]{2}{*}{$n$} & \multirow[b]{2}{*}{ Body wt (kg) } & \multirow{2}{*}{$\begin{array}{l}\text { Adrenal wt } \\
(\mathrm{mg} / \mathrm{kg})\end{array}$} & \multicolumn{3}{|c|}{ Intestinal protein $(\mathrm{mg} / \mathrm{g})$} \\
\hline & & & & & Proximal & Middle & Distal \\
\hline $82.2 \pm 0.5$ & Untreated & 5 & $0.44 \pm 0.05$ & $139 \pm 20$ & $69.7 \pm 8.8$ & $78.8 \pm 12.3$ & $71.6 \pm 10.7$ \\
\hline $89.1 \pm 0.2$ & Untreated & 8 & $0.60 \pm 0.04$ & $144 \pm 8$ & $85.1 \pm 9.2$ & $83.0 \pm 4.0$ & $75.1 \pm 5.8$ \\
\hline $93.2 \pm 2.0$ & Saline & 7 & $0.70 \pm 0.09$ & $189 \pm 14$ & $92.1 \pm 13.8$ & $85.4 \pm 5.2$ & $87.5 \pm 1.9$ \\
\hline $95.6 \pm 1.4$ & Cortisol & 16 & $0.79 \pm 0.07$ & $167 \pm 12$ & $107.6 \pm 6.4$ & $82.5 \pm 3.5$ & $95.1 \pm 3.0^{*}$ \\
\hline $99.3 \pm 0.5$ & Untreated & 10 & $0.82 \pm 0.07$ & $189 \pm 18$ & $94.7 \pm 4.6$ & $90.9 \pm 11.4$ & $85.2 \pm 6.0$ \\
\hline $107.3 \pm 0.3$ & Untreated & 16 & $0.97 \pm 0.06$ & $159 \pm 7$ & $117.8 \pm 6.9$ & $93.1 \pm 3.0$ & $100.1 \pm 4.8$ \\
\hline $114.9 \pm 0.1$ & Untreated & 9 & $1.20 \pm 0.07$ & $202 \pm 9$ & $122.6 \pm 4.8$ & $93.0 \pm 4.3$ & $97.1 \pm 6.4$ \\
\hline
\end{tabular}

* Mean value in cortisol-infused fetuses significantly higher than in saline-infused fetuses $(p<0.05)$.

of substrate hydrolyzed per min. Lactase activity [specific for lactase-phlorizin hydrolase (EC 3.2.1.23-62)] was measured in extracts (dilution 1:50) using lactose (Merck, Darmstadt, Germany) as substrate. Maltase activity, which arises from both sucrase-isomaltase (EC 3.2.1.48-10) and maltase-glucoamylase (EC 3.2.1.20), was measured in extracts (dilution 1:20) with glucose-free maltose (Merck) as substrate. Sucraseisomaltase accounts for approximately $80 \%$ of the total maltase activity in the adult pig intestine (20). Due to this overlap in enzyme specificities, maltase-glucoamylase content was determined by rocket immunoelectrophoresis using an antiserum against porcine maltase-glucoamylase (20). Enzyme levels were expressed relative to the maltase-glucoamylase concentration in a pool of newborn pig proximal intestines $[=1.0$ maltase-glucoamylase unit (MGU) per $\mathrm{g}$ of intestine]. The sucrase activity (specific for sucrase-isomaltase) was determined in undiluted extracts using sucrose $(\mathrm{BDH}$, Poole, $\mathrm{UK})$ as substrate.

Peptidase activities were measured spectrophotometrically at $410 \mathrm{~nm}$ (Cobas Fara, Roche, Switzerland) using specific nitroanilide substrates (21). Aminopeptidase N (EC 3.4.11.2) activity in extracts (dilution 1:500) was measured with $10 \mathrm{mM}$ L-alanine-4-nitroanilide (Merck) as substrate and $50 \mathrm{mM}$ Tris$\mathrm{HCl}, \mathrm{pH}$ 7.3, as buffer. Dipeptidyl peptidase IV (EC 3.4.14.5) activity in extracts (dilution 1:100) was measured with $15 \mathrm{mM}$ glycyl-L-proline-4-nitroanilide (Bachem, Bubendorf, Switzer-

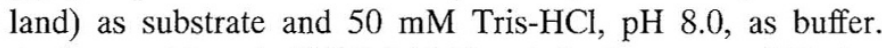
Aminopeptidase A (EC 3.4.11.7) activity in extracts (dilution 1:100) was measured with $10 \mathrm{mM} \alpha$-L-glutamic acid 4-nitroanilide (synthesized at the Institute of Protein Chemistry, Hørsholm, Denmark) as substrate and $50 \mathrm{mM}$ Tris- $\mathrm{HCl}, \mathrm{pH}$ 8.0 , as buffer.

Statistical analyses. Mean values \pm SEM are given throughout. Significant differences $(p<0.05)$ between two or more means were tested using analysis of variance and multiple $t$ test (22). A linear regression analysis was used to test the linear relationship between enzyme activities and fetal age or $\log _{10}$ plasma cortisol values in control fetuses that did not undergo an operation.

Within the infused fetuses (saline or cortisol), there was no significant effect of fetal age on plasma cortisol or enzyme activities at delivery $(p>0.05$, analysis of variance). Infused fetuses from each of the two infusion age groups (88-90 d and 97-102 d gestation) were therefore pooled in the presentation of results (Table 2 and Figs. 1-3). Significant differences ( $p<$
0.05 ) between cortisol-infused and saline-infused fetuses were tested by $t$ test for unpaired observations.

\section{RESULTS}

Fetal weights and total intestinal protein. Surgery and the insertion of catheters and osmotic minipumps had no effect on fetal body weight at the time of fetus removal (Table 2). Adrenal weight relative to body weight was significantly higher at term than at $82-84 \mathrm{~d}$ gestation $(p<0.05)$. The values in cortisol- and saline-infused fetuses were not significantly different $(p>0.05)$.

The mean intestinal protein content (Table 2) was higher at term than at $82-84 \mathrm{~d}$ gestation in all three regions of the small intestine (proximal, middle, and distal), but the difference was significant only in the proximal region. Similarly, the cortisolinfused fetuses showed higher mean values than the salineinfused fetuses, but the difference was significant only in the distal intestine. Because protein concentration of the tissues was affected to a variable degree by both age and treatment, the enzyme activities were expressed relative to intestinal wet weight.

Plasma cortisol. Endogenous fetal plasma cortisol rose gradually in late gestation and peaked at birth (Fig. 1). At the time of delivery, the cortisol group had a significantly higher concentration of cortisol in plasma than the saline group but also a lower concentration than in newborn control pigs. In the saline group, two fetuses looked emaciated at delivery and had

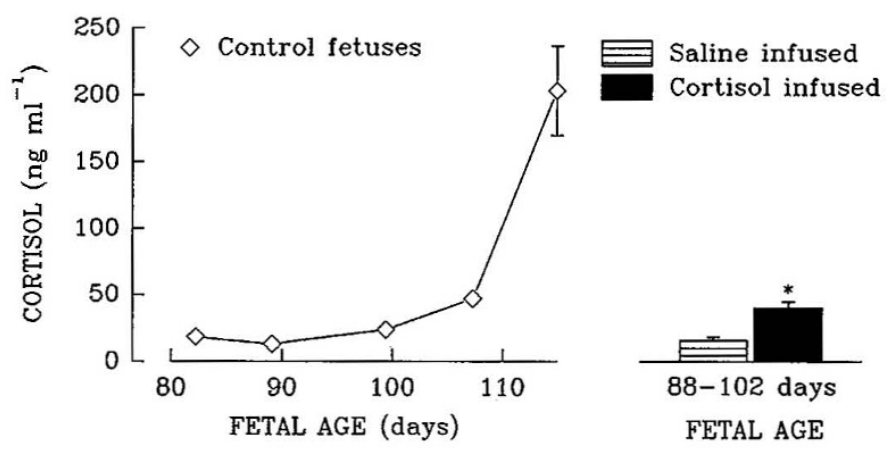

Figure 1. Plasma cortisol in fetal pigs (means \pm SEM). Values from control fetal and newborn pigs that did not undergo an operation (82-115 d gestation; left panel) are shown together with values from groups of fetuses infused with either saline or cortisol for $6 \mathrm{~d}$ preceding delivery from the uterus at $88-102$ $\mathrm{d}$ gestation (right panel). *, The mean value in cortisol-infused fetuses was significantly different from that in saline-infused fetuses $(p<0.05, t$ test). 

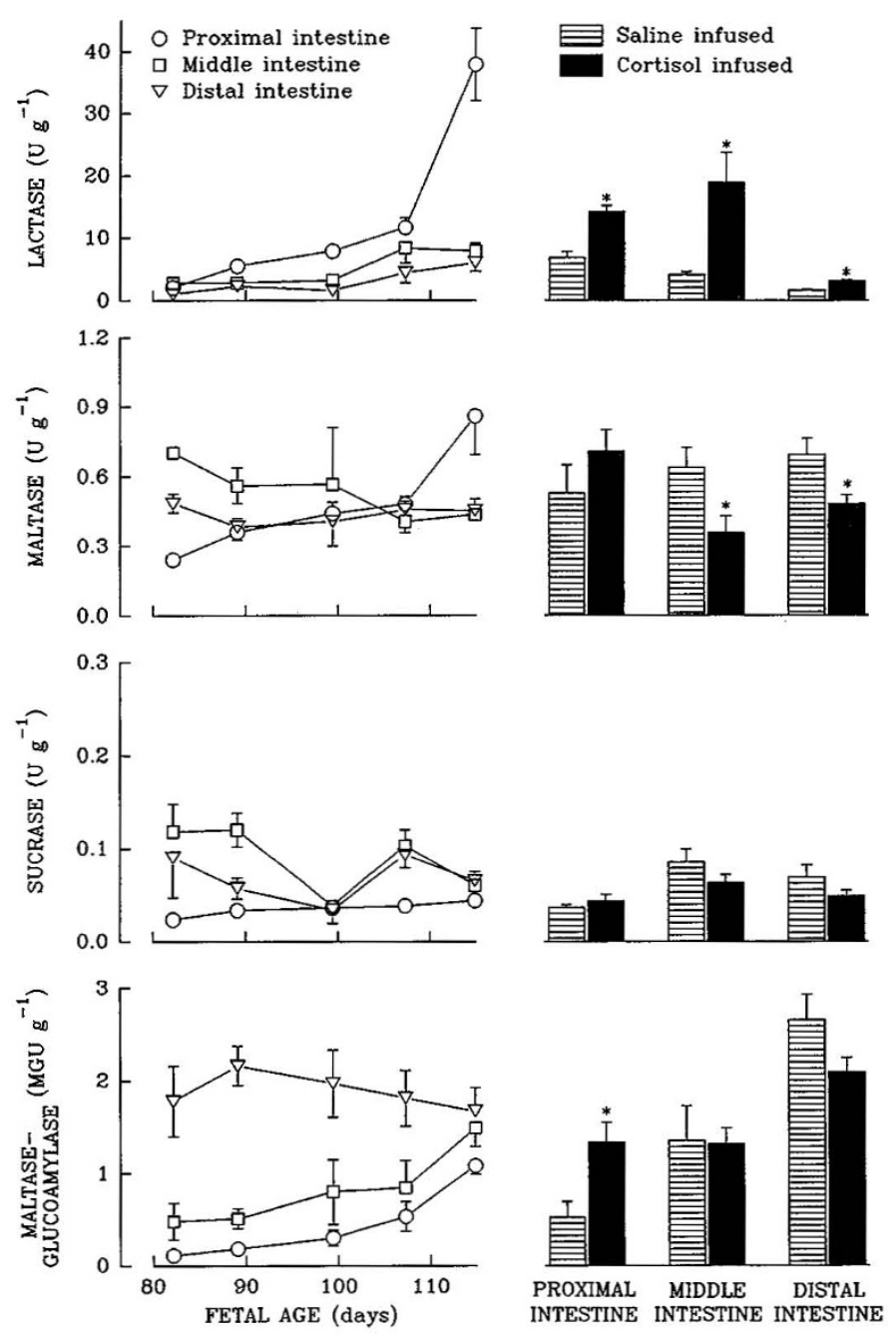

Figure 2. Disaccharidase activities (lactase, maltase, and sucrase) and the immunoreactive level of maltase-glucoamylase in the proximal, middle, and distal small intestine from control fetuses (left panels) and fetuses infused with cortisol or saline (right panels) (means \pm SEM). For further information, see legend to Figure 1.

excessively elevated plasma cortisol during the infusion period (30-80 $\mathrm{ng} / \mathrm{mL})$ compared with the remaining seven salineinfused fetuses $(15 \pm 3 \mathrm{ng} / \mathrm{mL})$. These two saline-infused fetuses with high endogenous cortisol levels have therefore not been included in the mean \pm SEM values shown in Table 2 and Figures 1-3.

Disaccharidases. Intestinal disaccharidase activities (lactase, maltase, and sucrase) and the relative enzyme concentration of maltase-glucoamylase are shown in Figure 2. In control fetuses that did not undergo an operation (Fig. 2, left panels), increases with fetal age occurred for lactase (proximal, middle, and distal regions), maltase (proximal region), and maltaseglucoamylase (proximal and middle regions). Significant positive correlations with both fetal age and $\log _{10}$ plasma cortisol values were found for these enzymes in the above mentioned regions $(r=0.46-0.80, p<0.05)$ except for the correlation between middle lactase activity and $\log _{10}$ plasma cortisol $(r=$ $0.40, p>0.05)$. Lactase activity was highest in the proximal region and by far the most abundant among the disaccharidases in the fetal pig intestine. Maltase and sucrase activities showed
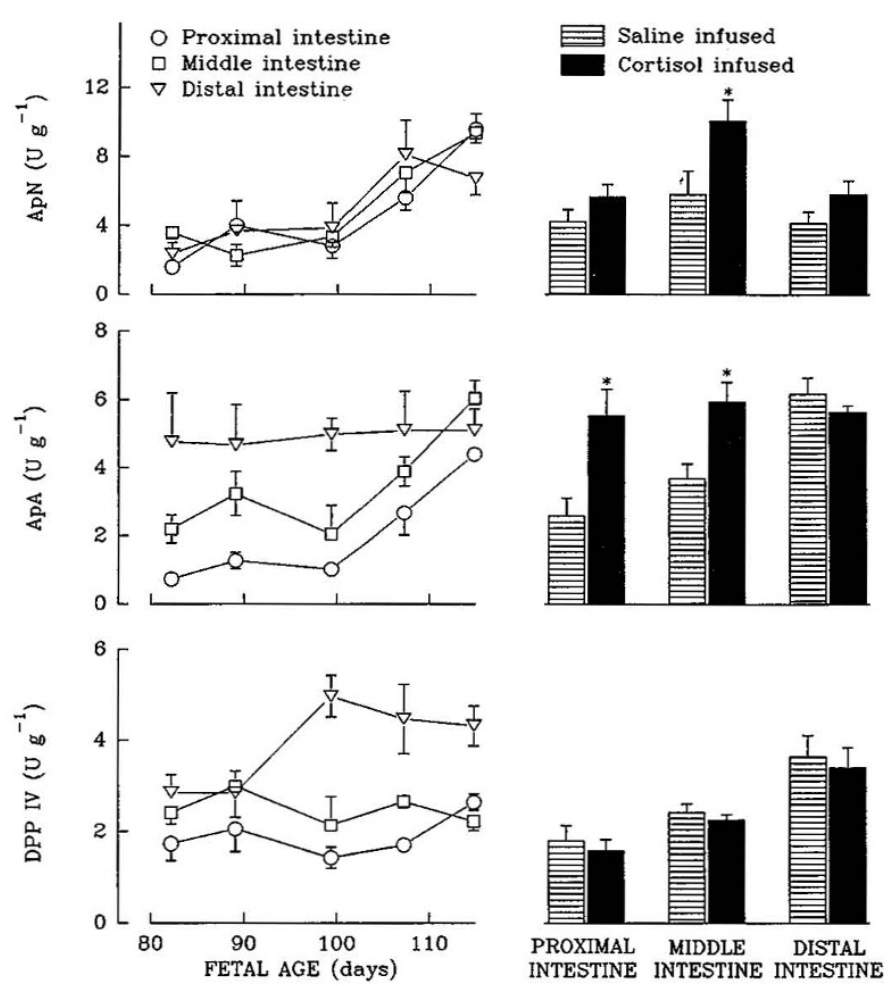

Figure 3. Peptidase $(A p N$, aminopeptidase $\mathrm{N} ; A p A$, aminopeptidase A; $D P P$ $I V$, dipeptidyl peptidase IV) activities in the proximal, middle, and distal small intestine from control fetuses (left panels) and fetuses infused with cortisol or saline (right panels) (means \pm SEM). For further information, see legend to Figure 1.

no clear differences in their longitudinal distribution, and sucrase activity in particular was low and quite variable. Maltaseglucoamylase protein in the distal intestine was significantly higher than in the proximal intestine.

Among the infused fetuses (Fig. 2, right panels), the cortisol group showed higher mean values for lactase (proximal, middle, and distal regions) and maltase-glucoamylase (proximal region) compared with the saline group. Maltase activity in the proximal region of cortisol-infused fetuses was significantly higher than in 97- to 102-d-old control fetuses $(p<0.05)$ but not higher than in the saline-infused fetuses. In the middle and distal regions, maltase activity was significantly lower in cortisol-infused fetuses than in saline-infused fetuses. No treatment differences were found for sucrase.

Peptidases. Peptidase activities are shown in Figure 3. In the control fetuses that did not undergo an operation (Fig. 3, left panels), increases with fetal age occurred for aminopeptidase $\mathrm{N}$ (proximal, middle, and distal regions) and aminopeptidase $\mathrm{A}$ (proximal and middle regions). Significant positive correlations with both fetal age and $\log _{10}$ plasma cortisol values were found for these enzymes in the above mentioned regions $(r=$ $0.51-0.89, p<0.05)$. Across fetal ages, dipeptidyl peptidase IV and aminopeptidase A activities were significantly higher in the distal region than in the proximal region, whereas aminopeptidase $\mathrm{N}$ was more equally distributed along the entire intestine.

Among the infused fetuses (Fig. 3, right panels), the cortisol group showed higher mean values for aminopeptidase $\mathrm{N}$ in the 
middle region and for aminopeptidase $\mathrm{A}$ in the proximal and middle regions. Although proximal aminopeptidase $\mathrm{N}$ activity in cortisol-infused fetuses was not significantly different from that in saline-infused fetuses, it was significantly higher than in 97- to 102-d-old control fetuses.

\section{DISCUSSION}

Circulating levels of glucocorticoid are elevated in the prepartum period of many species (23) and have important maturational effects on a wide range of tissues $(24,25)$. However, there is little experimental evidence for a role of glucocorticoids in the prenatal development of intestinal enzymes. In mammals, the activity of lactase increases rapidly in the late fetal period and peaks at or soon after birth, and the similarities between altricial species (e.g. rat, rabbit) and precocious species (pig, guinea pig, and human) have previously led to the suggestion that the timing of certain enzymatic changes is in some way related to the process of birth $(4,26)$. The present results indicate that the prepartum rise in circulating cortisol stimulates increases in lactase-phlorizin hydrolase, maltase-glucoamylase, aminopeptidase $\mathrm{N}$, and aminopeptidase A activity in the fetal pig intestine. This conclusion is supported by the effects of exogenous cortisol on enzyme activity in fetuses that underwent an operation and by the positive correlations of enzyme activity in controls that did not undergo an operation to plasma cortisol values. In this regard, the results extend our earlier findings that cortisol stimulates the prenatal rise in acid, gastrin, and protease secretion in the fetal pig stomach $(16,27)$, pancreatic amylase and trypsin contents (28), and liver glycogen deposition (17).

The stimulating effects of cortisol were not present, however, for all enzymes and intestinal regions investigated, and cortisol seems to have a regulatory role that is highly idiosyncratic for particular enzymes and intestinal regions. The stimulating effects were most pronounced in the proximal and middle part of the intestine. Such regional variation in the response to exogenous glucocorticoids is consistent with the fact that newborn pigs (peak plasma glucocorticoid levels) have 3- to 6-fold greater proximal:distal ratios in lactase (6:1), maltase-glucoamylase (1:2), aminopeptidase $\mathrm{N}$ (1:1), and aminopeptidase A (1:1) activity than fetal pigs $4-5 \mathrm{wk}$ before term. These proximal:distal ratios in newborn pigs are also greater than in postnatal pigs $(11,29)$ or humans adults $(30)$. The proximal:distal ratios for sucrase and dipeptidyl peptidase IV (enzymes that were not significantly affected by fetal age and cortisol) were similar at birth and at other stages of development.

The increase in proximal maltase-glucoamylase content in the cortisol group was reversed to a decrease in the distal intestine. This decrease in maltase-glucoamylase may, together with the slight, nonsignificant decreases in the sucrase activity, explain that exogenous cortisol treatment was associated with significant decreases in maltase activity in the middle and distal regions. It is possible that the age- and treatment-related increases in lactase and aminopeptidase activities to some extent occurred at the expense of sucrase and maltase activities and that enzymes compete for a limited biosynthetic capacity in differentiating enterocytes. In contrast to activities in human fetuses (3), maltase and sucrase activities in the intestine of the fetal pig were low, and these activities do not undergo major developmental increases until the postnatal period $(11,14,29)$. The lack of any stimulating effect on sucrase activity in fetal pigs is consistent with studies on neonatal pigs (11) but contrasts with the findings in rodents, where sucrase activity is readily inducible from the fetal stage (31). Our results underline the importance of direct maltase-glucoamylase measurements by immunologic techniques, inasmuch as maltase activity only represents the combined activity of two enzymes, maltase-glucoamylase and sucrase-isomaltase.

The value of extrapolation of results from one species to another or from one time point to another is always questionable. However, there is indirect evidence that cortisol plays a regulatory role in the developing human intestine. There is a marked gestational rise in fetal cortisol production (32) that correlates well with the increase in disaccaridase activities in the human fetus (3). In addition, exogenous glucocorticoid administration to pregnant mothers before preterm labor decreases the incidence of necrotizing enterocolitis in neonatal premature infants $(33,34)$.

The fact that plasma cortisol was significantly elevated during the infusion period in at least two of the saline-infused fetuses may be a consequence of the variable placental damage incurred to gain access to each fetus in this species (diffuse placenta). In these fetuses, levels of lactase and aminopeptidases in the proximal and middle intestine were $20-100 \%$ higher than in the remaining saline-infused fetuses. This is consistent with a role of cortisol per se in the prenatal pig intestine. Such stress effects of intrauterine surgery may explain why mean enzyme activities in saline-infused fetuses often were between the values observed for cortisol-infused and control piglets of similar age that did not undergo an operation.

Studies in the rat have led to the hypothesis that the developing intestinal cells are most responsive to glucocorticoids shortly before and during a normal developmental increase in enzyme activity (6). This hypothesis is consistent with the fact that elevated plasma glucocorticoids in suckling pigs do not stimulate proximal sucrase and maltase activity until $2-5 \mathrm{wk}$ of age when these enzyme activities normally increase rapidly $(11,13,14)$. At this stage, there is no glucocorticoid effect on lactase and aminopeptidase activities, which normally decrease postnatally $(13,14)$. The latter enzymes may therefore lose their responsiveness to glucocorticoid stimulation shortly before or at birth.

The mechanism by which glucocorticoids stimulate brushborder hydrolase activities is not known. In rodents, it is possible that the glucocorticoid-induced changes in enzyme activity mainly result from increases in enterocyte turnover and replacement of the villus cell population $(6,8,35)$. An increased enterocyte turnover has also been reported in the fetal sheep after cortisol administration (36). However, increased cell proliferation rate in young animals does not always lead to a simultaneous increase in sucrase activity and loss of lactase activity $(37,38)$, and hence other factors must be involved. In the newborn pig, changes in the fundamental biochemistry of 
existing enterocytes rather than cell replacement are likely to account for the age- and glucocorticoid-related enzymatic changes $(11,39)$. There is now substantial evidence that ageand glucocorticoid-related increases in the biosynthesis of enzyme protein are regulated at the transcriptional level, although changes in posttranslational modifications may also occur during development $(7,8,40-43)$. The observations in the present study and other studies showing that glucocorticoids affect only some enzymes and only in certain parts of the intestine certainly indicate a more sophisticated regulatory mechanism than that of a general increase in the mucosal cell proliferation rate or enterocyte biosynthetic capacity.

Acknowledgments. The authors thank Paul Hughes and Anni Mehlsen for expert technical assistance.

\section{REFERENCES}

1. Shulman RJ, Henning SJ, Nichols BL 1988 The miniature pig as an animal model for the study of intestinal enzyme development. Pediatr Res 23:311-315

2. Moughan PJ, Birtles MJ, Cranwell PD, Smith WC, Pedraza M 1992 The piglet as a model animal for studying aspects of digestion and absorption in milk-fed human infants. World Rev Nutr Diet 67:40-113

3. Grand JG, Watkins JB, Torti FM 1976 Development of the human gastrointestinal tract. A review. Gastroenterology 70:790-810

4. Moog F 1979 Endocrine influences on the functional differentiation of the small intestine. J Anim Sci 49:239-249

5. Koldovsky O 1985 Response of the gastrointestinal tract to premature weaning in experimental animals. Pediatrics 75(suppl):199-206

6. Henning SJ 1987 Functional development of the gastrointestinal tract. In: Johnson LR (ed) Physiology of the Gastrointestinal Tract, 2nd Ed. Raven Press, New York, pp 285-300

7. Yeh K-Y, Yeh M, Holt PR 1989 Differential effects of thyroxine and cortisone on jejunal sucrase expression in suckling rats. Am J Physiol 256:G604-G612

8. Leeper LL, Henning SJ 1990 Development and tissue distribution of sucraseisomaltase mRNA in rats. Am J Physiol 258:G52-G58

9. Majumdar APN 1981 Bilateral adrenalectomy. Effects of hydrocortisone and pentagastrin on the activity of intestinal disaccharidases and alkaline phosphatase in weanling rats. Scand J Gastroenterol 16:177-182

10. Silver M, Fowden AL 1989 Pituitary-adrenocortical activity in the fetal pig in the last third of gestation. Q J Exp Physiol 74:197-206

11. James PS, Smith MW, Tivey DR, Wilson TJG 1987 Epidermal growth factor selectively increases maltase and sucrase activities in neonatal piglet intestine. J Physiol 393:583-594

12. Chapple RP, Cuaron JA, Easter RA 1989 Effect of glucocorticoids and limiting nursing on the carbohydrate digestive capacity and growth rate of piglets. J Anim Sci 67:2956-2973

13. Kreikemeier KK, Harmon DL, Nelssen JL 1990 Influence of hydrocortisone acetate on pancreas and mucosal weight, amylase and disaccharidase activities in 14-day old pigs. Comp Biochem Physiol 97A:45-50

14. Sangild PT, Norén O, Sjöström H 1990 Development of intestinal brush border enzymes in the young pig and the effect of ACTH treatment. Zeitschr Gastroenterol 28:433(abstr)

15. Silver M 1980 Intravascular catheterization and other chronic fetal preparations in the mare and sow. In: Nathanielsz PW (ed) Animal Models in Fetal Medicine, Vol I. Elsevier/North-Holland, New York, pp 107-132

16. Sangild PT, Hilsted L, Nexø E, Fowden AL, Silver M 1994 Secretion of acid, gastrin and cobalamin-binding proteins by the fetal pig stomach: developmental regulation by cortisol. Exp Physiol 79:135-146

17. Fowden AL, Comline RS, Silver M 1985 The effects of cortisol on the concentration of glycogen in different tissues in the chronically catheterized fetal pig. Q J Exp Physiol 70:23-35
18. Silver M, Comline RS, Fowden AL 1983 Fetal and maternal endocrine changes during the induction of parturition with the PGF analogue, cloprostenol, in chronically catheterized sows and fetuses. J Dev Physiol 5:307-321

19. Lowry OH, Rosebrough N, Farr A, Randall RJ 1951 Protein measurement with the Folin phenol reagent. J Biol Chem 193:265-275

20. Sørensen SH, Norén O, Sjöström H, Danielsen EM 1982 Amphiphilic pig intestinal microvillus maltase/glucoamylase. Structure and specificity. Eur J Biochem 126:559568

21. Sjöström H, Norén O, Jeppesen L, Staun M, Svensson B, Christiansen L 1978 Purification of different amphiphilic forms of a microvillus aminopeptidase from pig small intestine using immunoadsorbent chromatography. Eur J Biochem 88:503-511

22. SAS 1988 In: SAS/STAT ${ }^{\text {TM }}$. Users Guide, 6.03 edition. SAS Institute Inc., Cary, NC, pp 549-640

23. Thorburn GD, Challis JRJ 1979 Endocrine control of parturation. Physiol Rev 59:863-918

24. Liggins GC 1976 Adrenocortical related maturational events in the fetus. Am J Obst Gynecol 126:931-939

25. Silver M 1990 Prenatal maturation, the timing of birth and how it may be regulated in domestic animals. Exp Physiol 75:285-307

26. Lamers WH, Mooren PG, Charles R 1985 Perinatal development of the small intestine and pancreas in rat and spiny mouse. Biol Neonate 47:153-162

27. Sangild PT, Silver M, Fowden AL, Turvey A, Foltmann B 1994 Adrenocortical stimulation of stomach development in the prenatal pig. Biol Neonate 65:378-389

28. Sangild PT, Weström BR, Fowden AL, Silver M 1992 Developmental regulation of the porcine exocrine pancreas by glucocorticoids. J Pediatr Gastroenterol Nutr 19:204-212

29. Kidder DE, Manners MJ 1980 The level and distribution of carbohydrases in the small intestine mucosa of pigs from 3 wk of age to maturity. Br J Nutr 43:141-153

30. Norén O, Sjöström H, Danielsen EM, Cowell EM, Skovbjerg H 1986 The enzymes of the enterocyte plasma membrane. In: Desnuelle $\mathrm{P}$, Sjöström H, Norén O (eds) Molecular and Cellular Basis of Digestion. Elsevier, Amsterdam, pp 335-365

31. Simon-Assmann P, Kedinger M, Grenier JF, Haffen K 1982 Control of brush border enzymes by dexamethasone in the fetal rat intestine cultured in vitro. J Pediatr Gastroenterol Nutr 1:257-265

32. Murphy BEP, Patrick J, Denton RL 1975 Cortisol in amniotic fluid during human gestation. J Clin Endocrinol Metab 40:164-167

33. Bauer CR, Morrison JC, Poole WK, Corones SB, Boehm JJ, Rigatto H, Zachman R 1984 A decreased incidence of necrotizing enterocolitis after prenatal glucocorticoid therapy. Pediatrics 73:682-688

34. Halac E, Halac J, Bégué EF, Casañas JM, Indiveri DR, Petit JF, Figueroa MJ, Olmas JM, Rodriguez LA, Obregón RJ, Martinez MV, Grinblat DA, Vilarrodona HO 1990 Prenatal and postnatal corticosteroid therapy to prevent neonatal necrotizing enterocolitis: a controlled trial. J Pediatr 117:132-138

35. Yeh K-Y, Yeh M, Holt PR 1987 Hormonal regulation of adaptive intestinal growth in artificially reared rat pups. Am J Physiol 253:G802-G808

36. Trahair JF, Perry RA, Silver M, Robinson PM 1987 Studies on the maturation of the small intestine in the fetal sheep. II. The effects of exogenous cortisol. Q J Exp Physiol 72:71-79

37. Yeh K-Y, Holt PR 1986 Ontogenetic timing mechanism initiates the expression of rat intestinal sucrase activity. Gastroenterology 90:520-526

38. Smith MW, Lloyd S, James PS 1988 Testing the hypothesis that crypt cell hyperplasia inhibits lactase expression by mouse jejunal enterocytes. Q J Exp Physiol 73:777-780

39. Smith MW 1985 Expression of digestive and absorptive function in differentiating enterocytes. Ann Rev Physiol 47:247-260

40. Danielsen EM, Cowell GM, Sjöström H, Norén O 1986 Translational control of an intestinal microvillar enzyme. Biochem J 235:447-451

41. Büller HA, Rings EHHM, Pajkrt D, Montgomery RK, Grand RJ 1990 Glycosylation of lactase-phlorizin hydrolase in the rat small intestine during development. Gastroenterology 98:667-675

42. Troelsen JT, Olsen J, Norén O, Sjötröm H 1992 A novel intestinal trans-factor (NF-LPH1) interacts with the lactase-phlorizin hydrolase promoter and co-varies with the enzymatic activity. J Biol Chem 267:20407-20411

43. Troelsen JT, Mehlum A, Olsen J, Spodsberg N, Hansen GH, Prydz H, Norén O, Sjöström H $19941 \mathrm{~kb}$ of the lactase-phlorizin hydrolase promoter directs postweaning decline and small intestinal-specific expression in transgenic mice. FEBS Lett 342:291-296 